\title{
Bank Privatization and Productivity: \\ Evidence for Brazil
}

\author{
Márcio I. Nakane \\ Central Bank of Brazil \\ University of Sao Paulo, Brazil \\ E-mail: marcio.nakane@bcb.gov.br
}

Daniela B. Weintraub

University of Sao Paulo, Brazil

E-mail: dbaumohl@uol.com.br

\begin{abstract}
Over the last decade, the Brazilian banking industry has undergone major and deep transformations with several privatizations of state-owned banks, mergers and acquisitions, closing down of troubled banks, entry by foreign banks, etc. The purpose of this paper is to evaluate the impacts of these changes in banking on total factor productivity. We first obtain measures of bank level productivity by employing the techniques due to Levinsohn and Petrin (2003). We then relate such measures to a set of bank characteristics. Our main results indicate that state-owned banks are less productive than their private peers, and that privatization has increased productivity.
\end{abstract}

Keywords: bank privatization, total factor productivity, Brazilian banking JEL Classification: G21, L33, O54

World Bank Policy Research Working Paper 3666, July 2005

The Policy Research Working Paper Series disseminates the findings of work in progress to encourage the exchange of ideas about development issues. An objective of the series is to get the findings out quickly, even if the presentations are less than fully polished. The papers carry the names of the authors and should be cited accordingly. The findings, interpretations, and conclusions expressed in this paper are entirely those of the authors. They do not necessarily represent the view of the World Bank, its Executive Directors, or the countries they represent. Policy Research Working Papers are available online at http://econ.worldbank.org. 


\section{Introduction}

The banking system in Brazil is the largest and the most complex one in Latin America. Like in many parts of the world, the banking industry in Brazil is undergoing a process of rapid and radical transformations. The common features of this process, in Brazil and elsewhere, include: an increase in competition from within the industry as well as from the outside; a wave of merger and acquisition (M\&A) activities, including several cross-border deals; more globalized capital markets with highly volatile capital flows, which are capable of causing havoc in some national financial sectors; new financial products, with increasing reliance on off-balance sheet activities; new banking practices brought out by the information technology revolution.

The banking sector in Brazil has been strongly influenced by the changing domestic macroeconomic scene of the recent period, especially by the transition from a high to a low inflation environment. After many years of making a living out of inflationary rents, this transition was far from smooth for many banks.

Among those most affected by the many changes in the industry were the stateowned banks. Due to their poor performance, many of the state-owned banks in Brazil were either closed down or privatized. Less than half (14) of the 32 state-owned banks operating in the country by 1994 were still active by 2002 .

The Brazilian experience represents an interesting case study on bank privatization not only because of its quantitative relevance but also due to the varied options given to the state-owned banks following their restructuring. Thus, some stateowned banks were straight privatized by their controllers (namely, the Brazilian states) whereas some others had their control first transferred from the states to the federal government and then privatized. Some other states also kept the control of their banks after restructuring. There are also some other state-owned banks that were just liquidated.

The purpose of this paper is to study the impact of the privatization of stateowned banks on productivity. Measures of bank-level total factor productivity are first obtained as the residuals from a production function estimate. The production function is estimated following the methodology suggested by Levinsohn and Petrin (2003) to try to control for endogeneity problems arising from the simultaneous choice of inputs and productivity by the bank firm. 
In a second stage, bank total factor productivity is related to a set of control variables. In an environment where many different types of corporate control changes are occurring simultaneously, it is important to try to control for as many of them as possible even though the primary interest of the paper lies on the effects of bank privatization. This is certainly the case for Brazil whereby privatization of state-owned banks were taking place alongside other corporate changes in the industry like domestic mergers and acquisitions, foreign acquisition of domestic banks, liquidation of banks, and pure exit from the market. We therefore follow the methodology proposed by Berger et al. (2003) and include variables controlling for static, selection, and dynamic effects. Static variables are dummies for groups of banks that have not had any corporate change over the sample period. Selection variables are dummies for groups of banks that have had some corporate change over the sample period. Such dummy variables are equal to one over the whole sample period for the corresponding banks. Dynamic variables are of two forms. A first set of dynamic variables are dummies for those banks that have had some corporate change over the sample period taking the value one only for the time periods following the change. A second set of dynamic variables track the number of time periods following the change. In addition to the static, selection, and dynamic variables we also included a set of dummy variables for those banks that have exited the market. Exit can occur either because the bank has been liquidated or because the bank has changed the nature of its activities.

Our main results show that state-owned banks are less productive than privateowned ones. Brazilian state-owned banks face severe agency problems due to their use for political, and social purposes. Another main result of the paper is that privatization has had a positive impact on productivity. Moreover, the positive effects of privatization seem to take some time to materialize. Privatization proved also to be a superior strategy than restructuring and keeping the bank under state control. On the other hand, we could not find any strong performance differences related to the way a state-owned bank was privatized (i.e., straight privatization or federalization followed by privatization).

This paper contributes to the literature on bank productivity. The study of bank productivity is relevant because productivity is a summary performance measure. Thus, productivity analysis may be relevant to those involved in bank M\&A issues, like bank practitioners or bank competition authorities. Also, to the extent that low productivity can work as an early warning, bank supervision authorities may use productivity 
measures as an additional monitoring instrument. Bank productivity studies are also useful due to the well-documented evidence that a bank system that efficiently channels available resources to productive uses is a powerful mechanism for economic growth [Levine (1997)].

This paper is also related to the literature on bank privatization. The empirical literature in this area takes the form of either cross-country studies or analyses of individual countries. ${ }^{1}$ This literature provides broad support to the conclusions reached in this paper on the poorer performance of state-owned banks and on the beneficial impacts of bank privatization.

This paper is structured as follows. Section 2 gives a brief overview of the banking industry in Brazil, with a special emphasis on the state-owned sector. Section 3 describes the methodology to be applied in the empirical sections. Section 4 discusses data-related issues. Section 5 estimates the coefficients of a production function, from which the bank-level productivity measures are calculated. Section 6 studies the determinants of bank productivity, highlighting the role played by bank privatization. Section 7 concludes the paper.

\section{Overview of the banking sector in Brazil}

The launching of the stabilization plan, called the Real Plan, in July 1994 with the subsequent transition to an environment of more stable prices proved to be very costly to the Brazilian banks. During the high-inflation period, banks could profit from inflation transfers. Inflation imposes a tax over the holders of money and non-interest bearing deposits. As issuers of demand deposits, commercial banks receive part of the inflation tax. According to ANDIMA-IBGE (1997), the inflationary transfers to the banking system fell from an average of $3.4 \%$ of GDP in the $1990-93$ period to $1.8 \%$ in 1994, and to $0.03 \%$ in 1995.

In the immediate aftermath of the stabilization plan, Brazilian banks tried to make up for the inflationary losses by increasing credit. Total loans of the financial

\footnotetext{
${ }^{1}$ Boehmer et al. (2003), Bonin et al. (2003), Otchere (2003), and Nguyen and Williams (2003) are examples of cross-country studies. Some studies focusing on individual countries are, among others, Berger et al. (2003) for Argentina, Beck, Crivelli, and Summerhill (2003) for Brazil, Beck, Cull, and Jerome (2003) for Nigeria, Haber and Kantor (2003) for Mexico, Omran (2003) for Egypt, and Bonaccorsi di Patti and Hardy (2003) for Pakistan. Megginson (2003) and Clarke et al. (2003) provide comprehensive surveys about bank privatization studies.
} 
system went up $43.7 \%$ after the first eight months of the stabilization plan. The rapid increase in the concession of loans was not followed by a careful consideration of the risk characteristics of those seeking credit. When the Central Bank dramatically increased the reserve requirements on deposits in the second half of 1994, coupled with the continuation of a policy of high interest rates, a credit retrenchment followed. Nonperforming loans started to accumulate fast.

With the imminent insolvency of some big private banks ${ }^{2}$ a bailout mechanism was put in place in November $1995^{3}$. Under this program, the Central Bank was given the mandate to compel a fragile bank to: a) increase its capital, or b) to transfer its shareholder control, or c) to be merged or acquired by another bank. PROER made easier for stronger financial institutions to acquire weaker ones by allowing the acquiring financial institutions to record as a premium the difference between the acquisition value and the market value of the acquired institution. Non-performing loans were recognized as losses and, under certain conditions, the premium could be used as a tax credit. It also allowed forbearance in the form of a temporary waive of the Basle minimum capital requirement for the ailing participants. In order to reduce the moral hazard problems associated to bailout schemes, PROER set out that banks could only qualify for official help when the ownership control was agreed to be transferred to some other institution. Seven banking institutions were restructured under the PROER resources.

The PROER program only reached private banks. A similar program aiming at the state-owned banks was launched in August 1996, the PROES ${ }^{4}$. The aim of this program was not only to reduce the participation of the Brazilian states (provinces) in the banking activity but also to address their chronic public debt problems ${ }^{5}$. Debt restructuring packages were offered to those states who agreed to give one of the following destinations to their banks: a) to liquidate it; b) to privatize it; c) to transfer its control to the federal government for future privatization, or, d) to transform it in a

\footnotetext{
${ }^{2}$ In August 1995, Banco Economico, the eight largest in the country by net worth, fell under Central Bank intervention. In November 1995, the same fate hit Banco Nacional, the sixth largest in the country by net worth.

${ }^{3}$ Program of Incentives to the Restructuring and Strengthening of the National Financial System, PROER.

${ }^{4}$ Program of Incentives to the Reduction of the State-Level Public Sector in the Bank Activity. See also Baer and Nazmi (2000), and Ness Jr. (2000) for more details.

${ }^{5}$ The two problems were not unrelated: state-level banks were the main purchasers of the public bonds issued by their main shareholders, the states themselves. Werlang and Fraga Neto (1995) study the role of state-owned banks in the creation of public debt. Bevilaqua (2000) describes state debt developments from the mid-1980s onwards, with special emphasis on the 1997 state debt bailout.
} 
development agency. Less favorable financial packages were also offered to those states that still wanted to keep their banks after bailing them out.

When PROES was launched, there were 35 financial institutions under the control of the Brazilian states, including 23 commercial banks. With the exception of the states of Mato Grosso do Sul, Tocantins (which had no financial institutions under their control), Paraíba, and Distrito Federal, all the other state units joined PROES. Under PROES, ten financial institutions were/are being liquidated, six banks were privatized by the states, six banks were/are being privatized by the federal government, sixteen financial institutions were transformed into development agencies, and five banks were restructured and kept under the state control ${ }^{6}$.

PROES only reached the banks owned by the states. For the banks owned by the federal government, an official restructuring program was launched in June 2001, the $\mathrm{PROEF}^{7}$. Under this program, many troubled assets were transferred to a newly created institution under the Finance Ministry control. Three federal government-owned banks (CEF, BNB, and Basa) also received capital injection ${ }^{8}$.

The whole set of measures put in place drastically changed the ownership composition of the banking sector in the country. Tables 1 and 2 document such changes along several dimensions.

TABLE 1 Number of Commercial Banks by Ownership

\begin{tabular}{|lcccccc|}
\hline Year & $\begin{array}{c}\text { Private } \\
\text { Domestic }\end{array}$ & $\begin{array}{c}\text { Minority } \\
\text { Foreign }\end{array}$ & $\begin{array}{c}\text { Control } \\
\text { Foreign }\end{array}$ & Public & TOTAL & $\begin{array}{c}\text { Number of } \\
\text { Privatizations }\end{array}$ \\
\hline 1994 & 146 & 31 & 37 & 32 & 246 & \\
1995 & 142 & 32 & 36 & 32 & 242 & \\
1996 & 130 & 29 & 40 & 32 & 231 & \\
1997 & 119 & 26 & 45 & 27 & 217 & 1 \\
1998 & 105 & 17 & 58 & 23 & 203 & 3 \\
1999 & 96 & 12 & 67 & 19 & 194 & 1 \\
2000 & 93 & 13 & 69 & 17 & 192 & 3 \\
2001 & 82 & 14 & 70 & 16 & 182 & 1 \\
2002 & 75 & 10 & 56 & 14 & 155 & 2 \\
\hline
\end{tabular}

\footnotetext{
${ }^{6}$ See Appendix 1 for a list of all banks included in the study with the identification of their corporate status.

${ }^{7}$ Program for the Strengthening of the Federal Financial Institutions.

${ }^{8}$ Banco do Brasil (BB), another federal government-owned bank, was capitalized by the Treasury back in 1995.
} 
The number of commercial banks operating in Brazil has been reducing since 1994. There were 91 fewer banks working in the country in 2002 than in 1994. Apart from foreign controlled banks, all the other bank segments showed considerable reductions in their numbers. Even for foreign controlled banks, the year 2002 represented a reversal of the trend when, after many years of continuing expansion, their number showed a reduction.

TABLE 2: Share of bank system balance sheet items by ownership

\begin{tabular}{|c|c|c|c|c|c|c|c|c|c|c|c|c|}
\hline \multirow[b]{2}{*}{ Year } & \multicolumn{3}{|c|}{ NET WORTH } & \multicolumn{3}{|c|}{ ASSETS } & \multicolumn{3}{|c|}{ DEPOSITS } & \multicolumn{3}{|c|}{ LOANS } \\
\hline & $\begin{array}{c}\text { Private } \\
\text { Domestic }\end{array}$ & Foreign & Public & $\begin{array}{c}\text { Private } \\
\text { Domestic }\end{array}$ & Foreign & Public & $\begin{array}{c}\text { Private } \\
\text { Domestic }\end{array}$ & Foreign & Public & $\begin{array}{c}\text { Private } \\
\text { Domestic }\end{array}$ & Foreign & Public \\
\hline 1994 & 56.03 & 9.64 & 34.33 & 41.29 & 7.17 & 51.53 & 39.41 & 4.59 & 56.00 & 35.47 & 5.20 & 59.34 \\
\hline 1995 & 49.93 & 13.27 & 36.80 & 39.25 & 8.41 & 52.34 & 36.48 & 5.41 & 58.11 & 31.93 & 5.75 & 62.32 \\
\hline 1996 & 56.03 & 10.42 & 33.55 & 39.12 & 9.82 & 51.06 & 34.18 & 4.37 & 61.45 & 32.91 & 8.70 & 58.39 \\
\hline 1999 & 47.55 & 25.93 & 26.53 & 33.33 & 23.34 & 43.33 & 32.07 & 16.93 & 50.99 & 32.03 & 19.98 & 48.00 \\
\hline 2000 & 51.35 & 28.88 & 19.76 & 35.50 & 27.62 & 36.88 & 34.28 & 21.36 & 44.36 & 34.96 & 25.48 & 39.56 \\
\hline 2001 & 52.19 & 31.35 & 16.45 & 37.55 & 30.13 & 32.32 & 35.80 & 20.41 & 43.79 & 42.82 & 32.03 & 25.15 \\
\hline 2002 & 49.74 & 33.62 & 16.64 & 37.32 & 27.67 & 35.01 & 37.16 & 20.13 & 42.71 & 40.45 & 30.48 & 29.07 \\
\hline
\end{tabular}

Table $2^{9}$ shows that private domestic banks managed to keep their share of the bank system net worth, assets, and deposits. This group of banks even increased their share of the bank system loans.

Foreign controlled banks increased significantly their market penetration in the country. In 2002, they accounted for $33.6 \%$ of the bank system net worth, $27.7 \%$ of the bank system assets, $20.1 \%$ of the bank system deposits, and $30.5 \%$ of the bank system loans.

Despite the great reduction in the importance of the state-owned banks, they still account for significant shares of the bank system net worth (16.6\%), assets (35\%), deposits (42.7\%), and loans (29.1\%).

\section{Methodology}

Productivity is defined as any variation in output that cannot be explained by variations in inputs. On this account, productivity changes can be due either to variations in efficiency or to changes in technology.

\footnotetext{
${ }^{9}$ In table 2, the foreign minority group is incorporated into the private domestic group.
} 
The methodology to be applied in this paper follows Levinsohn and Petrin (2003)' extension to the approach developed by Olley and Pakes (1996). Olley and Pakes' methodology allows one to consistently estimate the coefficients of a production function taking into consideration two possible sources of bias, namely a sample selection and a simultaneity bias.

The sample selection bias refers to the fact that many firms may have left the market during the sample period. It is reasonable to imagine that the unobservable productivity variable and the decision to leave the market are correlated, causing a potential sample selection problem. The simultaneity problem is related to the correlation between the unobservable productivity variable and the amount of inputs chosen by the bank. The selection problem is handled by modeling the exit decision by the firm. The simultaneity problem is solved by inverting an investment function, which is affected by the unobserved productivity.

Levinsohn and Petrin (2003) introduced an important improvement in the Olley and Pakes' methodology by making use of an intermediate input instead of investment as a proxy variable for productivity. Investment can only work as a valid proxy if it does not take zero values, which can be a very restrictive condition for the data sets typically found in developing countries.

Levinsohn and Petrin also argue that the monotonicity condition required for the inversion of the investment function may not be valid due to capital adjustment costs. The monotonicity condition for investment is then replaced by an equivalent requirement for an intermediate input function. The authors choose electricity as the productivity proxy on the account that all firms need such input. Moreover, in their sample, there was no firm producing or selling electricity, which can be interpreted as an impossibility for storing such input, making it highly correlated with contemporaneous productivity levels.

The procedure to be adopted in the estimation can be illustrated taking the example of a Cobb-Douglas production function:

$$
y_{i t}=\beta_{0}+\beta_{k} k_{i t}+\beta_{l} l_{i t}+\beta_{e} e_{i t}+\omega_{i t}+\eta_{i t}
$$

where $y_{i t}$ is the $\log$ of the output of firm $i$ in period $t, k_{i t}$ is the $\log$ of its capital stock, $l_{i t}$ is the log of its labor input, $e_{i t}$ is its electricity usage, $\omega_{i t}$ is its productivity, and $\eta_{i t}$ 
is an error stochastic term. Notice that both $\omega$ and $\eta$ are not observed by the econometrician. The difference between them is that $\omega$ is a state variable in the firm decision problem and therefore it affects the demand for inputs, while $\eta$ has no such implication.

Levinsohn and Petrin propose a two-step procedure to estimate the coefficients of (1) taking into consideration the simultaneity problem. ${ }^{10}$ In order to implement the first step, the inversion of the demand for electricity function, which is supposed to be strictly increasing in $\omega$, allows one to write:

$$
\omega_{t}=h_{t}\left(e_{t}, k_{t}\right)
$$

Equation (2) expresses the unobserved productivity variable as a function of observable variables. By replacing (2) in (1) it is possible therefore to control for $\omega$ in the estimation:

$$
y_{i t}=\beta_{l} l_{i t}+\varphi_{t}\left(e_{i t}, k_{i t}\right)+\eta_{i t}
$$

where:

$$
\varphi_{t}\left(e_{i t}, k_{i t}\right) \equiv \beta_{0}+\beta_{e} e_{i t}+\beta_{k} k_{i t}+h_{t}\left(e_{i t}, k_{i t}\right)
$$

The "partially linear" model (3)-(4) is a semiparametric regression model. The first step in the estimation allows the identification of the variable input coefficient $\beta_{l}$, but it does not allow the identification of the fixed input and of the electricity coefficients, $\beta_{k}$ and $\beta_{e}$, respectively.

The second step aims at estimating such coefficients. It begins with the assumption that productivity follows a first-order Markov process:

$$
\omega_{t+1}=\mathrm{E}\left[\omega_{t+1} \mid \omega_{t}\right]+\xi_{t+1}=g\left(\omega_{t}\right)+\xi_{t+1}=g\left[h_{t}\left(e_{i t}, k_{i t}\right)\right]+\xi_{t+1}
$$

\footnotetext{
${ }^{10}$ Unlike Olley and Pakes (1996), Levinsohn and Petrin (2003) do not account for the sample selection bias. Levinsohn and Petrin argue that the use of unbalanced panels controls, to some extent, for such bias. Moreover, both Olley and Pakes (1996) and Levinsohn and Petrin (1999) found that controlling for selection has little effect on the final parameter estimates.
} 
where $\xi_{t+1}$ is the innovation in $\omega_{t+1}$.

Lagging (5) one period, and replacing the result in (3), one obtains:

$$
\begin{aligned}
& y_{i t}-\beta_{l} l_{i t}=\beta_{0}+\beta_{e} e_{i t}+\beta_{k} k_{i t}+h_{t}\left(e_{i t}, k_{i t}\right)+\eta_{i t}=\beta_{0}+\beta_{e} e_{i t}+ \\
& +\beta_{k} k_{i t}+g\left[\varphi_{t-1}\left(e_{i t-1}, k_{i t-1}\right)-\beta_{0}-\beta_{e} e_{i t-1}-\beta_{k} k_{i t-1}\right]+\xi_{i t}+\eta_{i t}
\end{aligned}
$$

Expression (6) requires the knowledge of $\varphi_{t-1}$, which can be estimated in the first-step. Equation (6) is then used to estimate $\beta_{e}$ and $\beta_{k}$ by non-linear least squares.

\section{Data and sample}

The empirical section of the paper aims at estimating a Cobb-Douglas production function having a measure of bank output as the dependent variable and three productive inputs as explanatory variables.

The inputs are labor, capital, and intermediate inputs. Following Levinsohn and Petrin (2003), a separate intermediate input is used as a proxy variable for productivity. Unlike the manufacturing sector, however, the use of electricity as a proxy variable in the banking industry does not seem to be warranted. We therefore take communications as our proxy for the unobserved productivity. Other intermediate inputs are the sum of water, electricity, and gas bill costs, maintenance costs, non-durable goods acquisition costs, data processing costs, and transport costs.

Capital stock includes premises, equipment, other fixed assets, and rented/leased premises and equipment. It is net of depreciation. Capital stock is treated as a fixed input since adjustment costs may prevent instantaneous reallocations of such input. Thus, beginning-of-period values of capital stock are used in the estimations. As for labor, we treat it alternatively as a variable and as a fixed factor. ${ }^{11}$

Measurement of bank output is more controversial, with many approaches being proposed in the literature ${ }^{12}$. Here, output is measured as the value of total bank working assets (total assets less fixed assets), making our model consistent with the

\footnotetext{
${ }^{11}$ Labor economists in Brazil argue that, due to rigid labor market legislation, dismissal of labor force is very costly. Such friction can prevent instantaneous reallocations of the labor input making it behave as a fixed factor.

${ }^{12}$ See, among others, Berger and Humphrey (1992), and Fixler and Zieschang (1992).
} 
intermediation approach. Haynes and Thompson (1999) use a similar procedure. Some empirical studies use bank deposits either as output or as input of the bank activity. However, because of the relevance of bank deposits in the liability side of a bank balance sheet, the inclusion of them would cause a serious problem in the estimation of the production function, due to the accounting identity equating total assets and total liabilities. In the present study therefore bank deposits are not included in the bank production process.

We also report results for a broader measure of output, attempting to take into consideration off balance sheet activities by the banks. We proxy such activities by the total income of services, and we add them to total bank working assets.

The source of the accounting data is COSIF (Accounting Plan of the National Financial System Institutions), elaborated by the Brazilian Central Bank, and by which all the financial institutions operating in the country have to report balance sheet and income statements on a monthly basis. The accounts for (end of) June and (end of) December of each year during the period from December 1990 to December 2002 were used. Constant values were obtained deflating the nominal values through the evolution of the IGP-DI, the general price index calculated by Fundação Getúlio Vargas (FGV). All constant values were converted to December 2002 values.

The sample is unbalanced with 242 commercial banks. All the observations with zero values for the output or for one of the inputs were excluded from the analysis. In addition, banks with less than three observations, and outliers were also excluded. The final sample contains 4,444 observations $^{13}$. Table 6 in Appendix 2 shows some descriptive statistics for the sample variables.

\section{Estimation of bank productivity}

This section implements Levinsohn and Petrin (2003) methodology to obtain measures of productivity for a sample of Brazilian banks. In the next section, the banklevel productivity measures so obtained are regressed on a number of control variables,

\footnotetext{
13 The criterion employed to eliminate the outliers was the following: initially, the ratios of output to labor, of output to capital, and of output to intermediate inputs were computed for all the valid observations. The observations in the lower $0.5 \%$ and in the upper $0.5 \%$ for each of the three ratios were excluded from the sample.
} 
including, among them, dummy variables representing privatization of state-owned banks.

Levinsohn and Petrin (2003) modify Olley e Pakes (1996) approach in two ways. First, they replace investment by electricity as a proxy variable for productivity. Second, they do not model the exit decision by the bank. For the sample of Brazilian banks, troubled banks stop reporting employment levels to the Central Bank, which preclude us to implement the second step in Olley and Pakes algorithm. As Levinshohn and Petrin argue, we hope that the use of unbalanced panel data helps to reduce the sample selection bias.

The first step of the algorithm involves the estimation of the following "partially linear” equation:

$$
y_{i t}=\beta_{0}+\beta_{l} l_{i t}+\beta_{i} i_{i t}+\beta_{c} c_{i t}+\beta_{k} k_{i t}+h_{t}\left(c_{i t}, k_{i t}\right)+t i m e_{t}+\varepsilon_{i t}
$$

where $y_{i t}$ is the log of bank output, $l_{i t}$ is the log of labor, $i_{i t}$ is the log of other intermediate inputs, $c_{i t}$ is the log of communications, $k_{i t}$ is the log of capital, time $e_{t}$ is a trend variable, and $\varepsilon_{i t}$ is the random error term.

The $h_{t}\left(c_{i t}, k_{i t}\right)$ function is estimated by means of a polynomial series expansion where terms of up to the fourth degree of $c_{i t}$ and $k_{i t}$ are used. This series expansion is separately estimated for three different sub-periods: from 1990 to June 1994, from December 1994 to 1997, and from 1998 to 2002. In equation (7) labor is considered as a variable factor. We also estimated models where labor is treated as a fixed factor. When this is the case, labor is also incorporated in the polynomial series expansion.

The first step of the estimation allows one to obtain consistent estimates of the variable factor coefficients, $\beta_{l}$ and $\beta_{i}$. Once these coefficients are obtained, we compute the term:

$$
y_{i t}^{p}=y_{i t}-\hat{\beta}_{l} l_{i t}-\hat{\beta}_{i} i_{i t}
$$

This term is then regressed on a polynomial series in $\left(c_{i t}, k_{i t}\right)$. The fitted value from this regression is denoted $\hat{\varphi}_{t}\left(c_{i t}, k_{i t}\right)$. 
In the second step, consistent estimates for $\beta_{c}$ and $\beta_{k}$ are obtained through non-linear least squares applied to:

$$
y_{i t}^{p}=\beta_{0}+\beta_{c} c_{i t}+\beta_{k} k_{i t}+g\left[\hat{\varphi}_{t-1}\left(c_{i t-1}, k_{i t-1}\right)-\beta_{0}-\beta_{c} c_{i t-1}-\beta_{k} k_{i t-1}\right]+\xi_{i t}+\varepsilon_{i t}
$$

where $\xi_{i t}$ is the innovation term in productivity.

Table 3 presents the production function coefficients estimated through the Levinsohn and Petrin (L-P) algorithm, alongside the coefficients obtained through least squares estimation. The results are shown for the two measures of output. ${ }^{14}$

TABLE 3 - Estimates of production function parameters

\begin{tabular}{|c|c|c|c|c|c|c|}
\hline & \multicolumn{2}{|c|}{ Least Squares } & \multicolumn{2}{|c|}{ L-P - variable labor } & \multicolumn{2}{|c|}{ L-P - fixed labor } \\
\hline & Assets & $\begin{array}{l}\text { Assets + } \\
\text { Services }\end{array}$ & Assets & $\begin{array}{l}\text { Assets + } \\
\text { Services }\end{array}$ & Assets & $\begin{array}{l}\text { Assets + } \\
\text { Services }\end{array}$ \\
\hline In (labor) & $\begin{array}{c}-0.0479 * \\
(-1.90)\end{array}$ & $\begin{array}{c}-0.0476^{*} \\
(-1.89)\end{array}$ & $\begin{array}{c}-0.0750 \text { *** } \\
(-3.30)\end{array}$ & $\begin{array}{c}-0.0748^{\star \star * *} \\
(-3.30)\end{array}$ & $\begin{array}{c}0.4409^{\star \star \star *} \\
(4.17)\end{array}$ & $\begin{array}{c}0.4384^{* \star *} \\
(4.41)\end{array}$ \\
\hline In (other intermediate) & $\begin{array}{c}0.2599 * * \star \\
(9.03)\end{array}$ & $\begin{array}{c}0.2602^{\star \star \star} \\
(9.06)\end{array}$ & $\begin{array}{c}0.2137^{\star \star \star} \\
(8.21)\end{array}$ & $\begin{array}{c}0.2139 \star \star \star \\
(8.25)\end{array}$ & $\begin{array}{c}0.4391^{* * *} \\
(19.74)\end{array}$ & $\begin{array}{c}0.4393^{* * *} \\
(19.82)\end{array}$ \\
\hline In (communications) & $\begin{array}{c}0.6162^{\star * \star} \\
(22.94)\end{array}$ & $\begin{array}{c}0.6159 * \star \star \\
(23.02)\end{array}$ & $\begin{array}{c}0.6119 * \star \star \\
(8.68)\end{array}$ & $\begin{array}{c}0.6205^{\star \star \star} \\
(9.61)\end{array}$ & $\begin{array}{c}0.2047^{\star \star *} \\
(4.80)\end{array}$ & $\begin{array}{c}0.20436^{\star \star *} \\
\quad(4.22)\end{array}$ \\
\hline In (capital) & $\begin{array}{c}0.0236 \\
(1.50)\end{array}$ & $\begin{array}{c}0.0241 \\
(1.54)\end{array}$ & $\begin{array}{c}0.0515^{\star} \\
(1.89)\end{array}$ & $\begin{array}{c}0.0432 \\
(1.54)\end{array}$ & $\begin{array}{l}0.064 \\
(1.07)\end{array}$ & $\begin{array}{c}0.0651 \\
(1.13)\end{array}$ \\
\hline time & $\begin{array}{c}0.0482^{\star \star \star} \\
(20.96)\end{array}$ & $\begin{array}{c}0.0483^{\star \star \star} \\
(21.08)\end{array}$ & $\begin{array}{c}0.0379 * \star \star \\
(6.06)\end{array}$ & $\begin{array}{c}0.0378^{\star \star \star} \\
(6.08)\end{array}$ & $\begin{array}{c}0.0546^{\star * *} \\
(8.24)\end{array}$ & $\begin{array}{c}0.0547^{\star \star \star} \\
(8.29)\end{array}$ \\
\hline Observations & \multicolumn{2}{|c|}{4444} & \multicolumn{2}{|c|}{4202} & \multicolumn{2}{|c|}{4202} \\
\hline
\end{tabular}

The estimated coefficients are quite robust to the use of different measures of output. The labor coefficients in the least squares estimations are negative, and marginally significant. When labor is treated as a variable factor in the L-P approach, its coefficient becomes even more negative and highly significant this time. The last two columns of Table 3 show the estimates of the L-P approach when labor is treated as a fixed factor. This model shows more reasonable values for the estimated coefficients, although the statistical significance of the capital stock coefficient is still low ${ }^{15}$. Thus,

\footnotetext{
14 The standard errors of the coefficients for the fixed inputs and for communications in the L-P models were obtained by bootstrap resampling 100 times. There are fewer observations in the L-P models due to the use of lagged terms in the estimation of (9).

${ }^{15}$ The results are robust to different cutoff values for the outliers $(0.5 \%, 1 \%, 2 \%)$, and also to different degrees for the polynomial expansion series (fourth and fifth degrees).
} 
for the remaining of the analysis, the coefficients shown in the last two columns of Table 3 are used as the estimates for the bank production function.

As discussed in section 3 , it is important that monotonicity with respect to productivity holds for the communications input. If this assumption is violated, we cannot invert this function to express productivity as a function of observable variables. In order to check the validity of this assumption, communications was regressed on productivity and on the fixed inputs (capital and labor). All the estimated coefficients are positive and significant.

Bank-level (log of) total factor productivity is computed as the difference between actual and fitted output, given by:

$$
\omega_{i t}=y_{i t}-\hat{\beta}_{l} l_{i t}-\hat{\beta}_{i} i_{t}-\hat{\beta}_{c} c_{i t}-\hat{\beta}_{k} k_{i t}
$$

Aggregate bank productivity is calculated as the weighted bank-level productivity for each period, where the weight is given by the market share of each bank product in each time period. Figure 1 shows the evolution of the aggregate productivity alongside a more standard measure of productivity, namely labor productivity (calculated as the weighted average of $y_{i t}-l_{i t}$ ), both normalized to one in June $1990 .^{16}$

\footnotetext{
${ }^{16}$ Both total factor productivity and labor productivity take the broader measure of output. Plots for the productivities using only assets as the measure of output give virtually the same display.
} 
Figure 1: Brazilian banking system: total factor, and labor productivity

(June $1990=1$ )

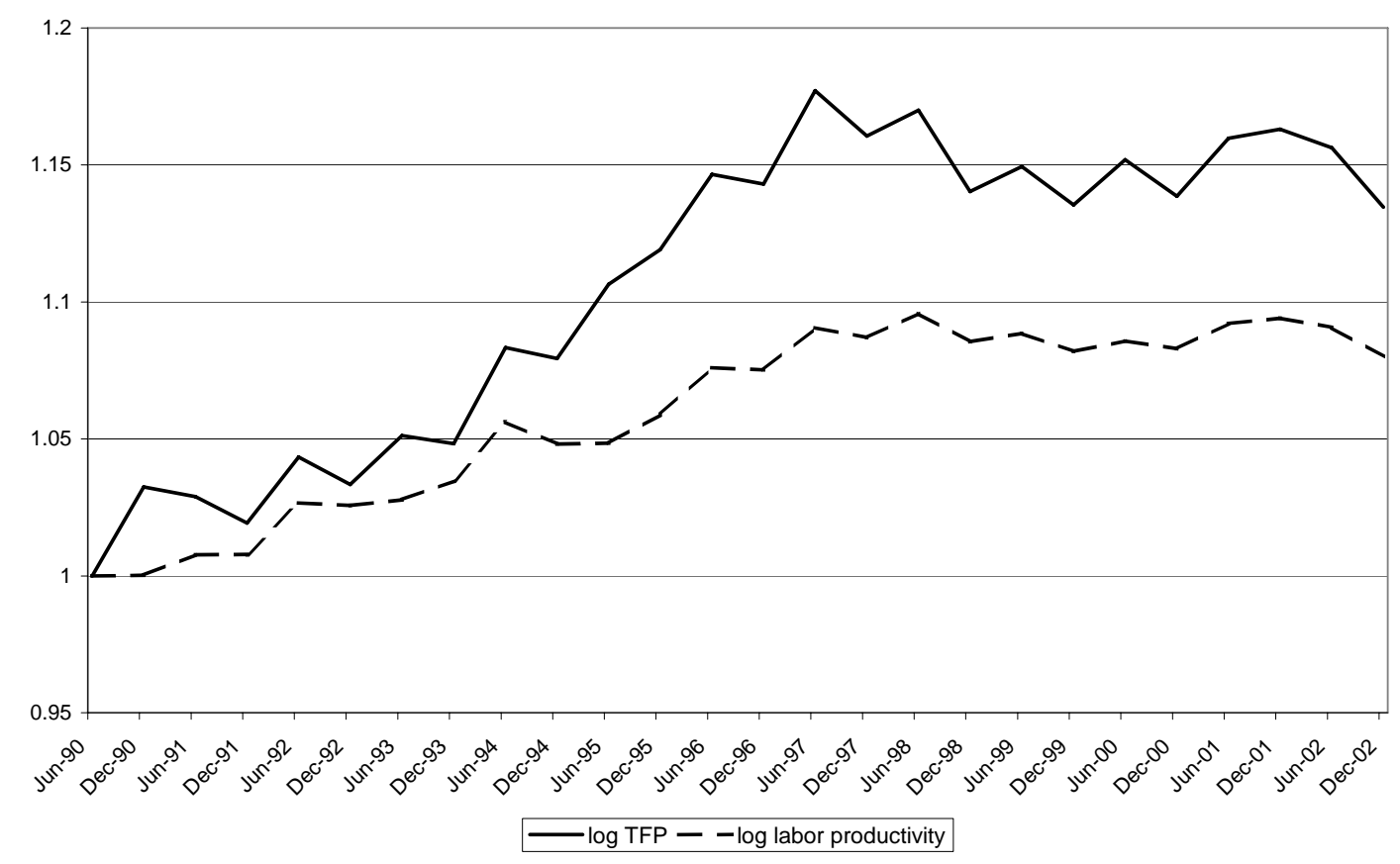

The two aggregate productivity measures display similar temporal patterns although their numerical scales differ. It is interesting to notice that labor productivity underestimates total factor productivity in banking, which is the opposite of what is found for the manufacturing sector in Brazil [Muendler (2002), Schor (2004)]. One possible reason for these differences may be related to a large fall in the capital stock in banking over the 1990's, whereas the opposite is found in the manufacturing sectors in Brazil.

Aggregate total factor productivity increases up to June 1997, remaining fairly flat after it. The accumulated productivity growth over the entire period is $13.46 \%$, or an average annual growth rate of $1.02 \%$. There is great heterogeneity across sub-periods though. In the period from June 1990 to June 1997, the average annual growth rate reached 2.36\%. From June 1997 to December 2002, there is actually a small fall in the aggregate productivity: there is an accumulated fall of $3.61 \%$ or an average annual fall of $0.67 \%$.

Nakane (1999) found similar results through the estimation of cost functions for Brazilian banks accounting for efficiency according to the stochastic frontier 
methodology ${ }^{17}$. According to his estimation, the average cost efficiency index for Brazilian banks reached 0.4151 in the June 1990 to June 1994 period, and increased to 0.5098 in the June 1994 to June 1997 period. Bevilaqua and Loyo (1998) also document cost efficiency gains for a panel of 38 Brazilian banks during the last quarter of 1994 and the second quarter of 1998.

Table 4 reports summary statistics for (the log of) total factor productivity according to different bank groups. ${ }^{18}$

TABLE 4 Descriptive Statistics for Productivity Scores

\begin{tabular}{|l|c|c|c|c|c|}
\hline & Mean & Median & $\begin{array}{c}\text { Standard } \\
\text { Deviation }\end{array}$ & Minimum & Maximum \\
\hline All Banks - 244 banks, 4444 observations & & & & & \\
TFP1 & 7.81 & 7.72 & 1.38 & 4.48 & 13.00 \\
TFP2 & 7.81 & 7.72 & 1.37 & 4.54 & 12.99 \\
Labor Productivity1 & 14.84 & 14.80 & 1.45 & 10.69 & 20.33 \\
Labor Productivity2 & 14.85 & 14.81 & 1.45 & 10.71 & 20.33 \\
TFP2 by Bank Size & & & & & \\
1st Decile - 79 banks, 445 observations & 7.09 & 7.11 & 0.87 & 4.82 & 10.56 \\
2nd Decile - 98 banks, 445 observations & 7.62 & 7.50 & 1.01 & 5.17 & 11.27 \\
3rd Decile - 106 banks, 445 observations & 7.84 & 7.77 & 1.15 & 4.54 & 11.55 \\
4th Decile - 115 banks, 445 observations & 7.96 & 7.98 & 1.38 & 4.77 & 12.36 \\
5th Decile - 108 banks, 444 observations & 8.29 & 8.39 & 1.41 & 4.85 & 11.98 \\
6th Decile - 103 banks, 444 observations & 8.09 & 8.33 & 1.42 & 4.93 & 11.68 \\
7th Decile - 97 banks, 444 observations & 8.06 & 8.41 & 1.50 & 5.12 & 11.97 \\
8th Decile - 78 banks, 444 observations & 8.11 & 8.29 & 1.57 & 5.24 & 12.56 \\
9th Decile - 66 banks, 444 observations & 7.90 & 7.59 & 1.48 & 5.38 & 12.99 \\
10th Decile - 38 banks, 444 observations & 7.18 & 6.92 & 1.25 & 5.19 & 11.84 \\
TFP2 by Bank Ownership & & & & & \\
State owned - 32 banks, 591 observations & 6.29 & 6.36 & 0.62 & 4.54 & 8.58 \\
Foreign - 71 banks, 996 observations & 8.43 & 8.42 & 1.15 & 5.46 & 11.84 \\
Domestic - 168 banks, 2857 observations & 7.91 & 7.84 & 1.33 & 4.82 & 12.99 \\
TFP2 for Privatized Banks - 14 banks & & & & & \\
Privatized banks - 306 observations & 6.39 & 6.37 & 0.71 & 4.85 & 8.58 \\
Pre Privatization - 259 observations & 6.25 & 6.28 & 0.64 & 4.85 & 8.58 \\
Post Privatization - 47 observations & 7.13 & 7.07 & 0.56 & 6.13 & 8.36 \\
\hline
\end{tabular}

TFP1 is log of total factor productivity when output is measured as total assets.

TFP2 is log of total factor productivity when output is measured as the sum of total assets and services. Labor Productivity1 is log of labor productivity when output is measured as total assets. Labor Productivity2 is log of labor productivity when output is measured as the sum of total assets and services. Bank size is measured as the sum of total assets and services.

The average productivity scores have an inverted $U$ shape across bank size. Small and large banks are the least productive ones. Bank total factor productivity increases steadily up to the 5th decile of bank size, decreasing for larger groups.

\footnotetext{
${ }^{17}$ See Berger and Humphrey (1997) for a survey of efficiency studies applied to banking.

${ }^{18}$ We only report the results for the broader measure of output. The results are the same when the narrower measure is used.
} 
When banks with different ownership structures are considered, state-owned banks form the least productive group, followed by the group of private domestic banks. Foreign-owned banks are the most productive group of banks. Finally, table 4 reports considerable improvements in productivity following privatization.

The results shown in Table 4 should be interpreted as unconditional measures. In particular, no causal relations can be inferred from such figures. In the following section, we report regression results controlling for a rich set of explanatory variables. The main purpose is to uncover productivity differences accruing from corporate changes, especially changes related to bank privatization.

\section{Determinants of bank productivity}

This section attempts to study the determinants of bank productivity. Special attention is paid to the role of the ownership structure. In face of an environment whereby different corporate changes are affecting the industry, Berger et al. (2003) argue that it is important to control for as many of the changes as possible. In other terms, even if the primary interest of the paper relies on the effects of bank privatization, the introduction of controls for corporate changes that do not involve state-owned banks (e.g. domestic M\&As or foreign acquisition of domestic banks) are overdue.

Moreover, Berger et al. (2003) develop a framework where static, selection, and dynamic effects are contemplated. Static effects refer to the differences in performance for groups of banks that have not been involved in any corporate change. Selection effects are those related to the performance differentials for the groups of banks that were involved in some ownership change. Finally, dynamic effects capture the changes in performance for the last group of banks that are due to the change in ownership. This framework has been applied to study the Argentinean case by Berger et al. (2003), the Brazilian case by Beck, Crivelli, and Summerhill (2003), and the Nigerian case by Beck, Cull, and Jerome (2003).

The Brazilian case seems to be well suited for an application of this methodology. First, many corporate changes affected the banking industry in the 1990’s, involving bank privatization, domestic M\&As, foreign acquisition of domestic banks, and bank closures. Second, as documented in section 2, the process of bank 
privatization was very rich in Brazil. Public banks owned by states were offered different solutions to their banks, including, liquidation, outright privatization, federalization followed by privatization, and restructuring.

Static dummy variables were created for those banks that did not face any ownership change over the sample period and were still active by the end of the sample period. Two static dummy variables were created for state-owned banks (dstatic_state), and for foreign-controlled banks (dstatic_foreign). These dummy variables take the value one for the corresponding bank for all the time periods. Domestic private banks are the excluded reference group.

Out of the 242 banks with observations in the sample ${ }^{19}, 112$ (46.28\%) of them were active by December 2002 without experiencing any corporate change. Five (2.07\% of the total) of them were state-owned banks, 64 (26.45\%) of them were domestic private banks, and 43 (17.77\%) of them were foreign controlled banks.

The relevance of each group of banks cannot be entirely gauged by their respective numbers due to the presence of many small banks. We therefore computed the market share of each group in December 2002. On this account, the group of commercial banks that have not experienced any corporate change responded for $79.94 \%$ of the market share. The market shares accounted by state-owned banks, domestic private banks, and foreign controlled banks are, respectively, 32.52\%, 28.25\%, and $19.17 \%$.

Selection dummy variables were created for those banks that have faced some corporate change over the sample period. Four selection dummy variables were created for state-owned banks that were directly privatized (dselection_privatized), for stateowned banks that were first federalized and later privatized $(\text { dselection_federalized_privatized })^{20}$, for state-owned banks that were restructured and kept under state ownership (dselection_restructured), and for domestic private banks acquired by other private banks (dselection_domestic). The selection dummy variables take the value one for the corresponding banks during all the time periods. ${ }^{21}$

\footnotetext{
${ }^{19}$ See Appendix 1 for a list of all the banks included in the sample together with their organizational status and (when applicable) their status changes. Appendix 2 presents summary statistics for all the variables included in the regressions for the determinants of bank productivity.

${ }^{20}$ We also included in this group four state-owned banks that were federalized and have not been privatized by the end of the sample period.

${ }^{21}$ For some few banks, there was more than one change of control. In such cases, we followed Berger et al. (2003)'s procedure and only consider the last change.
} 
Out of the 242 commercial banks in the sample, 55 (22.73\%) of them have had some form of control change. State-owned banks account for 19 (7.85\% of the total) of the cases with 7 privatized banks, 7 federalized and privatized banks, and 5 reestructured state-owned banks. ${ }^{22}$ Of the remaining 36 cases (14.88\% of the total) involving private banks, half of them are cases of domestic banks merging with other domestic banks whereas the other half are situations where domestic banks are being acquired by foreign ones. In terms of market share, the group of banks that were involved in any form of corporate change accounted for $20.06 \%$ of the market in December 2002. The market shares of the state-owned banks, of the domestic banks acquired by other domestic banks, and of the domestic banks acquired by foreign banks are, respectively, of 9.51\%, 5.17\%, and 5.37\%.

Dynamic dummy variables were created for those banks for which the selection dummies were equal to one to date the precise moment when the ownership change occurred. Five dynamic dummy variables were created for state-owned banks that were straight privatized (ddynamic_privatized), for state-owned banks that were first federalized and later privatized dating the time of federalization (ddynamic_federalized_privatized_datefederalization), for state-owned banks that were first federalized and later privatized dating the time of privatization (ddynamic_federalized_privatized_dateprivatization), for state-owned banks that were restructured and kept under state ownership dating the time of restructuring (ddynamic_restructured), and for domestic private banks acquired by other private banks (ddynamic_domestic). The dynamic dummy variables take the value one for the corresponding banks for all the time periods following a certain intervention.

The dynamic dummy variables capture the once-and-for-all changes associated to the interventions. However, in addition to this level effect, the interventions can have differentiated impacts over time. We therefore also created variables measuring the time lapsed since the intervention. Since we use 6-month observations in our sample, such variables are measured in semesters. Six time variables were created, one for each dynamic dummy variable. The labels for such variables follow the same pattern as the ones defined for the dynamic dummy variables with time replacing ddynamic. For example, time_federalized_privatized_datefederalization measures the time since a state-owned bank that was federalized and privatized was federalized. Typically, the

\footnotetext{
${ }^{22}$ A caveat is in order. The small number of privatized banks in the sample may harden the precise
} identification of the impacts of privatization on bank performance. 
time variables take the value one in the semester when the intervention occurred, the value two in the following semester, and so on.

We follow Berger et al. (2003) and actually exclude from the sample all observations for which the time variables equal one. In other terms, the semester during which the intervention occurred is not considered in the sample. The reason for this treatment is to try to control for noise introduced during the event of intervention, which usually produces some discontinuities in previous policies, involves legal costs associated to the intervention, etc.

In addition to the static, selection, and dynamic variables we created another group of variables to deal with the banks that exited the market. ${ }^{23}$ Typically, banks have left the market either because they were liquidated or because they changed their activities from commercial banking into something else. Accordingly, we defined three exit dummy variables for liquidated state-owned banks (dexit_liquidated_state), for liquidated private banks (dexit_liquidated_private), and for commercial banks that changed their activities (dexit_change). The exit dummy variables take the value one for the corresponding banks during all the periods for which they are present in the sample.

Out of the 242 commercial banks present in our unbalanced sample, 75 (30.99\%) of them have exited the market. Six (2.48\% of the total) state-owned banks were liquidated, 23 (9.50\%) private banks were liquidated, and 46 (19.01\%) commercial banks changed their activities. Obviously, the market share of the exited banks is zero by December 2002.

In addition to the above mentioned variables we also included three additional control variables given by the lagged market share (market_share), as measured by the share of each bank output in the sector output in each period, lagged bank size given by the number of bank branches (branches), and lagged return (return), as measured by the ratio of pre tax profits to net worth. Time dummies were also included in the estimated regressions, with the aim of capturing macroeconomic effects not accounted for in the estimation.

Table 5 presents four sets of results for the determinants of bank productivity. The reported results differ according to the two measures of output and according to whether the "time" variables capturing the effects of corporate changes over time are

\footnotetext{
${ }^{23}$ Beck, Crivelli, and Summerhill (2003) work with a balanced sample, excluding such banks from their analysis. We believe that keeping these banks in the sample is important to better deal with the sample selection problems discussed in section 3.
} 
included or not. Robust standard errors are computed throughout. The coefficients of the time dummies are not reported to spare space.

TABLE 5 - Determinants of Log(TFP)

\begin{tabular}{|c|c|c|c|c|}
\hline Variable & \multicolumn{2}{|c|}{ TFP1 } & \multicolumn{2}{|c|}{ TFP2 } \\
\hline $\begin{array}{l}\text { dstatic_state } \\
\text { dstatic_foreign }\end{array}$ & $\begin{array}{c}-1.0517^{\star \star \star} \\
(0.0903) \\
0.3229 * * \star \\
(0.0494)\end{array}$ & $\begin{array}{c}-1.0517^{\star \star \star} \\
(0.0903) \\
0.3231^{\star \star \star} \\
(0.0494)\end{array}$ & $\begin{array}{c}-1.0431^{\star \star \star} \\
(0.0894) \\
0.3209^{\star \star \star} \\
(0.0492)\end{array}$ & $\begin{array}{c}-1.0430 * * \star \\
(0.0894) \\
0.3211^{\star * \star} \\
(0.0493)\end{array}$ \\
\hline dexit_liquidated_state & $\begin{array}{l}-1.9858^{\star \star \star} \\
(0.1046)\end{array}$ & $\begin{array}{c}-1.9861^{\star \star \star} \\
(0.1047)\end{array}$ & $\begin{array}{c}-1.9729 * \star \star \\
(0.1035)\end{array}$ & $\begin{array}{c}-1.9732^{\star \star \star} \\
(0.1035)\end{array}$ \\
\hline dselection_privatized & $\begin{array}{l}-1.3949 * \star \star \\
(0.0729)\end{array}$ & $\begin{array}{l}-1.3957^{\star * \star} \\
(0.0730)\end{array}$ & $\begin{array}{l}-1.3845^{\star \star \star} \\
(0.0726)\end{array}$ & $\begin{array}{c}-1.3853^{\star \star \star} \\
(0.0727)\end{array}$ \\
\hline ddynamic_privatized & $\begin{array}{c}0.4997^{\star \star \star} \\
(0.1137)\end{array}$ & $\begin{array}{c}0.0390 \\
(0.1710)\end{array}$ & $\begin{array}{l}0.4996 * \star \star \\
(0.1126)\end{array}$ & $\begin{array}{c}0.0364 \\
(0.1698)\end{array}$ \\
\hline ddynamic_federalized_privatized_datefederalization & $\begin{array}{l}-0.0578 \\
(0.0818)\end{array}$ & $\begin{array}{l}0.0115 \\
(0.1668)\end{array}$ & $\begin{array}{l}-0.0574 \\
(0.0811)\end{array}$ & $\begin{array}{c}0.0157 \\
(0.1652)\end{array}$ \\
\hline ddynamic_federalized_privatized_dateprivatization & $\begin{array}{l}0.3880 * * \\
(0.1857)\end{array}$ & $\begin{array}{l}-0.3334 \\
(0.5332)\end{array}$ & $\begin{array}{l}0.3856^{\star *} \\
(0.1824)\end{array}$ & $\begin{array}{l}-0.3220 \\
(0.5211)\end{array}$ \\
\hline $\begin{array}{l}\text { ddynamic_restructured } \\
\text { ddynamic_domestic }\end{array}$ & $\begin{array}{c}-0.2359 \star \star \\
(0.1092) \\
0.2819 \star \star \\
(0.1142)\end{array}$ & $\begin{array}{c}-0.2216 \\
(0.1971) \\
0.2847 \\
(0.1899)\end{array}$ & $\begin{array}{l}-0.2319^{\star *} \\
(0.1086) \\
0.2837^{\star \star} \\
(0.1134)\end{array}$ & $\begin{array}{c}-0.2200 \\
(0.1958) \\
0.2873 \\
(0.1887)\end{array}$ \\
\hline market_share & $\begin{array}{l}19.2719 * * * \\
(2.6595)\end{array}$ & $\begin{array}{l}19.2493^{\star \star \star} \\
(2.6575)\end{array}$ & $\begin{array}{l}19.1296 * * * \\
(2.6396)\end{array}$ & $\begin{array}{c}19.1071^{\star \star \star} \\
(2.6376)\end{array}$ \\
\hline $\begin{array}{l}\text { branches } \\
\text { return }\end{array}$ & $\begin{array}{c}-0.0018 * * \star \\
(0.00015) \\
0.0062 \\
(0.0091)\end{array}$ & $\begin{array}{c}-0.0018 * \star \star \\
(0.00015) \\
0.0062 \\
(0.0091)\end{array}$ & $\begin{array}{c}-0.0018 * \star \star \\
(0.000015) \\
0.0062 \\
(0.0091)\end{array}$ & $\begin{array}{c}-0.0018 * \star \star \\
(0.00015) \\
0.0062 \\
(0.0091)\end{array}$ \\
\hline constant & $\begin{array}{c}7.1432^{\star \star \star} \\
(0.1032)\end{array}$ & $\begin{array}{l}7.1436 * \star \star \\
(0.1033)\end{array}$ & $\begin{array}{l}7.1441^{* \star *} \\
(0.1027)\end{array}$ & $\begin{array}{c}7.1444^{\star \star \star} \\
(0.1028)\end{array}$ \\
\hline Observations & 4147 & 4147 & 4147 & 4147 \\
\hline R-squared & 0.3673 & 0.3675 & 0.3668 & 0.3670 \\
\hline
\end{tabular}

Robust standard errors in parentheses; ${ }^{\star},{ }^{\star \star},{ }^{\star \star \star}$ indicate significant at 10, 5, and 1 percent, respectively.

TFP1 is total factor productivity when output is measured as total assets.

TFP2 is total factor productivity when output is measured as the sum of total assets and services.

All specifications include semester fixed effects (not shown). 
The two static dummy variables are highly significant in all specifications. The results show that state-owned banks are less productive than the private domestic ones (the reference group). On the other hand, foreign banks are more productive than the private domestic group.

In addition to agency problems, one possible reason for the lower productivity of state-owned banks in Brazil is the "social” role they play as government agents. Thus, Banco do Brasil and CEF are major players in the concession of loans to the rural and to the low-income housing sector, respectively, usually at subsidized rates.

The three exit dummy variables are significant in every specification and one of them is positive. State-owned liquidated banks have the poorest performance within this group, followed by the private liquidated banks. Commercial banks that left the market were actually more productive than the active private domestic banks (reference group). One possible reason for some banks to leave the market is related to the increasing costs of staying in the bank business related to more stringent prudent regulations as well as to the introduction of the new payment system in the country during 2002.

Three of the four selection dummy variables are highly significant and negative in all specifications. In addition, these three selection variables are all related to stateowned banks. Overall, state-owned banks that underwent some corporate change are less productive than private banks that also faced some corporate change. The selection coefficient is non-significant for the latter group, indicating that their productivity is no different than the productivity of the reference group (active domestic private banks).

As for the state-owned banks, the group of banks that were first federalized and later privatized has the worst performance. Wald tests show that the coefficients for the selection variables for this group are significantly different than the coefficients for the other groups for all four specifications.

The estimated coefficients for the static, exit, and selection dummy variables are quite robust to the different measures of output and to the inclusion of the "time" variables. On the other hand, the dynamic dummy variables differ markedly according to whether the "time" variables are included or not. When they are not included, only one out of the five dynamic dummy variables is not statistically significant.

The most significant dynamic impacts we detected are related to bank privatization. Bank performance significantly improved after privatization. Moreover, the method of privatization does not seem to be relevant. Although the impacts of privatization are estimated to be greater for the banks that were straight privatized 
(when compared to the banks that were first federalized and later privatized), the differences are not statistically significant. ${ }^{24}$

The other significant positive dynamic variable is associated to corporate changes involving only private banks. In other terms, private banks that were merged or acquired by other private banks have their performance improved following consolidation.

Two of the dynamic variables are negatively signed with one of them being significant. Both of them are related to state-owned banks during periods of restructuring (either under federal or under state control). This result is not surprising because restructuring usually involves the transfer of troubled assets to the federal government. Since total assets are our measure of output, such banks may be facing a reduction in output while keeping unchanged their levels of inputs and therefore reducing their productivity.

It is worth mentioning that the alternative of restructuring the state-owned bank and keeping it under state control does not seem to yield good results. Following their restructuring, the productivity of this group of banks has significantly decreased.

Overall, the results suggest that dynamic effects associated both to bank privatization and to corporate control changes in the private sector worked towards improving the productivity of the involved banks.

When the dynamic impacts of the corporate changes are allowed to take effect over time, only the groups of banks that were privatized showed significant improvements in productivity. In other terms, the impacts of bank privatization on productivity seem to spread out over many periods. And, again, the method of privatization does not seem to matter much. Although the coefficients on the "over time" effects of privatization are greater for the banks that were first federalized and then privatized, the differences are not statistically significant. ${ }^{25}$

With regard to the other control variables included in the regressions reported in Table 5, the results indicate a positive effect of lagged market share, a negative effect of the lagged number of branches on bank productivity, and non-significant impacts of the lagged return. These results change very little in the four specifications. The positive

\footnotetext{
24 The tests that the dynamic effects for state-owned banks that were straight privatized and for stateowned banks that were first federalized and then privatized are equal give $F$ statistics of 0.26 (p-value equal to 0.6070 ) in the regression for TFP1 and 0.28 (p-value equal to 0.5940 ) in the regression for TFP2.

${ }^{25}$ The tests that the "over time" effects for state-owned banks that were straight privatized and for stateowned banks that were first federalized and then privatized are equal give $F$ statistics of 1.44 (p-value equal to 0.2299 ) in the regression for TFP1 and 1.45 (p-value equal to 0.2293 ) in the regression for TFP2.
} 
effect for market share suggests that the "quite life" hypothesis [Berger and Hannan (1998)], according to which banks with greater market power are less likely to take additional steps to be more productive, does not seem to be a good representation of the behavior of the Brazilian banks. Notice that the use of lagged market share helps to control for a possible reverse causality channel whereby more productive banks have an edge to increase their market shares. On the other hand, the negative effect for the number of bank branches may be pointing out to scale diseconomies. The operation of extensive branch networks can impart on productivity if the branches are small and geographically dispersed.

Summing up, our results suggest that state-owned banks are less productive than their private peers. We also showed that privatization of state-owned banks improves productivity, regardless of the way the privatization takes place. In special, the beneficial effects of privatization are spread out over many periods. Finally, restructuring the state-owned banks and keeping it under state control does not seem to be a dominant strategy.

\section{Conclusions}

In the 1990s, the Brazilian banking sector underwent huge transformations. Following the control of the inflationary process, there was an intense wave of mergers and acquisitions, involving not only domestic agents but also foreign banks. Many stateowned banks were privatized; some of them were closed down. Many troubled private banks also went bust. Improved bank regulation and supervision were also put into action. The purpose of this study was to evaluate how bank productivity was affected by these changes. Particular attention was paid to the effects of the privatization of stateowned banks.

The empirical sections of the paper made use of unbalanced panel data for 242 commercial banks, observed twice a year, from December 1990 to December 2002. Bank-level productivity measures were obtained as the difference between actual and expected output, where the latter is the fitted value from the estimation of a production

function. The estimated production function follows the strategy suggested by Levinsohn and Petrin (2003) to account for endogeneity problems. 
In the second stage of the investigation, we tried to evaluate the role of some control variables on the level of bank productivity. Given the varied nature of corporate changes during the sample period, we follow Berger et al. (2003) and try to control for static, selection, and dynamic effects. We also include dummy variables controlling for exited banks. The results show a positive association between productivity and bank market share. It also shows negative effects from the number of bank branches on productivity. Moreover, state-owned banks seem to be less productive than their private competitors. Bank privatization had positive “over time” impact on productivity but restructuring the state-owned banks and keeping it under state control has negative effects on productivity.

The way a state-owned bank is privatized does not seem to matter. Some stateowned banks in Brazil were straight privatized by their former controllers whereas some other ones were first federalized and then privatized. The results show that the positive impacts of privatization do not differ for these two groups of banks.

\section{Appendix 1: List of the banks included in the sample}

Banks with no corporate change

\begin{tabular}{|ll|}
\hline Bank Name & Status \\
\hline Banco do Brasil & State \\
BASA Banco da Amazonia & State \\
BNB Banco do Nordeste do Brasil & State \\
BRB Banco de Brasília & State \\
Caixa Econômica Federal & State \\
Banco ABN AMRO Real & Foreign \\
Banco American Express & Foreign \\
Banco Barclays & Foreign \\
Banco BNL do Brasil & Foreign \\
Banco BNP Pariabas Brasil S. A. & Foreign \\
Banco Citibank & Foreign \\
Banco CNH Capital & Foreign \\
Banco Comercial Uruguai & Foreign \\
Banco Daimlerchrysler & Foreign \\
Banco de la Nacion Argentina & Foreign \\
Banco de la Provincia de Buenos Aires & Foreign \\
Banco de la Republica Oriental del Uruguay & Foreign \\
Banco de Tokyo-Mitsubishi Brasil & Foreign \\
Banco Fiat & Foreign \\
Banco Ford & Foreign \\
\hline
\end{tabular}


Banco General Motors

Banco Gerdau

Banco Honda

Banco HSBC

Banco J. P. Morgan

Banco KEB do Brasil

Banco Pottencial

Banco PSA Finance Brasil

Banco Rabobank International Brasil

Banco Sudameris Brasil

Banco Sumitomo Mitsui Brasileiro

Banco Toyota do Brasil

Banco Union Brasil

Banco Uno E - Brasil

Banco Volkswagen

Banco Volvo Brasil

Banco Westlb do Brasil

Bank of America

BankBoston

BankBoston N.A.

Citibank N.A.

Deutsche Bank

Dresdner Bank Brasil

Dresdner Bank Lateinamerika Aktiengesellschaft

HSBC Bank Brasil

ING Bank N.V.

JP Morgan Chase Bank

Lloyds TSB Bank PLC

Banco A. J. Renner

Banco Arbil

Banco BBM

Banco BGN

Banco BMC

Banco BMG

Banco Bonsucesso

Banco Bradesco

Banco BRJ

Banco BVA

Banco Cacique

Banco Capital

Banco Cedula

Banco Classico

Banco Cooperativo do Brasil

Banco Cooperativo Sicredi

Banco Credibel

Banco Cruzeiro do Sul

Banco Daycoval

Banco Emblema

Banco Fator

Banco Fibra
Foreign

Foreign

Foreign

Foreign

Foreign

Foreign

Foreign

Foreign

Foreign

Foreign

Foreign

Foreign

Foreign

Foreign

Foreign

Foreign

Foreign

Foreign

Foreign

Foreign

Foreign

Foreign

Foreign

Foreign

Foreign

Foreign

Foreign

Foreign

Private domestic

Private domestic

Private domestic

Private domestic

Private domestic

Private domestic

Private domestic

Private domestic

Private domestic

Private domestic

Private domestic

Private domestic

Private domestic

Private domestic

Private domestic

Private domestic

Private domestic

Private domestic

Private domestic

Private domestic

Private domestic

Private domestic 
Banco Ficsa

Banco Guanabara

Banco Industrial do Brasil

Banco Industrial e Comercial

Banco Indusval

Banco Intercap

Banco Itau

Banco J. Safra

Banco Luso Brasileiro

Banco Matone

Banco Máxima

Banco Maxinvest

Banco Mercantil do Brasil

Banco Modal

Banco Opportunity

Banco Ourinvest

Banco Pactual

Banco Panamericano

Banco Paulista

Banco PEBB

Banco Pecunia

Banco Pine

Banco Prosper

Banco Rede

Banco Rendimento

Banco Ribeirão Preto

Banco Rural

Banco Rural Mais

Banco Safra

Banco Santos

Banco Simples

Banco Sofisa

Banco Triangulo

Banco Votorantim

Banco VR

Banco Zogbi

Banco1.NET

BancoSchahin

BancoTricury

Parana Banco

Sterling Participações e Empreendimentos

UNIBANCO União de Bancos Brasileiros
Private domestic

Private domestic

Private domestic

Private domestic

Private domestic

Private domestic

Private domestic

Private domestic

Private domestic

Private domestic

Private domestic

Private domestic

Private domestic

Private domestic

Private domestic

Private domestic

Private domestic

Private domestic

Private domestic

Private domestic

Private domestic

Private domestic

Private domestic

Private domestic

Private domestic

Private domestic

Private domestic

Private domestic

Private domestic

Private domestic

Private domestic

Private domestic

Private domestic

Private domestic

Private domestic

Private domestic

Private domestic

Private domestic

Private domestic

Private domestic

Private domestic

Private domestic

Banks that changed corporate control

\begin{tabular}{|lll|}
\hline Bank Name & Status & $\begin{array}{l}\text { Date of Change of } \\
\text { Status }\end{array}$ \\
\hline Banco BANEB & Straight Privatized & July 1999 \\
Banco BANERJ & Straight Privatized & July 1997 \\
Banco BANESTADO & Straight Privatized & October 2000 \\
\hline
\end{tabular}




\begin{tabular}{|l} 
Banco BEMGE \\
Banco de Credito Real de Minas \\
Gerais \\
Banco de Pernanbuco - \\
BANDEPE \\
PARAIBAN - Banco da Paraiba \\
Banco BEA \\
Banco BEG \\
Banco BEM \\
Banco do Estado de Santa \\
Catarina \\
Banco do Estado de Sao Paulo \\
- BANESPA \\
Banco do Estado do Ceara - \\
BEC \\
Banco do Estado do Piaui - \\
BEPI \\
Banco do Estado de Sergipe \\
Banco do Estado do Para \\
Banco do Estado do Rio Grande \\
do Sul \\
Banco Nossa Caixa \\
BANESTES Banco do Estado \\
do Espirito Santo \\
American Express Bank \\
Banco ABC Brasil \\
Banco Alvorada \\
Banco Banif Primus \\
Banco BBM \\
Banco BCN \\
Banco Inter-Atlantico \\
Banco Boavista Interatlantico \\
Banco Brascan \\
Banco Itau-BBA \\
Banco Calyon Brasil \\
Banco Cidade \\
Banco Cindam \\
Banco Comercial e de \\
Investimento Sudameris \\
Banco Credibanco \\
Banco Credit Suisse First \\
Boston \\
Banco das Nações \\
Banco Dibens \\
Banco Digibanco \\
Bancost \\
Banco Brasileiro \\
Banco
\end{tabular}

Straight Privatized

Straight Privatized

Straight Privatized

Straight Privatized

Federalized and Privatized

Federalized and Privatized

Federalized and Privatized

Federalized and Privatized

Federalized and Privatized

Federalized and Privatized

Federalized and Privatized

Reestructured

Reestructured

Reestructured

Reestructured

Reestructured

Domestic to Private

Domestic to Private

Domestic to Private

Domestic to Private

Domestic to Private

Domestic to Private

Domestic to Private

Domestic to Private

Domestic to Private

Domestic to Private

Domestic to Private

Domestic to Private

Domestic to Private

Domestic to Private

Domestic to Private

Domestic to Private

Domestic to Private

Domestic to Private

Domestic to Private

Domestic to Private

Domestic to Private

Domestic to Private

Domestic to Private

Domestic to Private
September 1998

January 1998

November 1998

November 2001

Federalized in Oct 99;

Privatized in Feb 02

Federalized in Oct 99;

Privatized in Dec 01

Federalized in Sep 00

Federalized in Sep 00

Federalized in Dec 97;

Privatized in Nov 00

Federalized in Oct 99

Federalized in Mar 00

4th Quarter 1998

4th Quarter 1998

1st Quarter 1998

4th Quarter 2000

4th Quarter 1997

November 1998

December 1997

October 1998

December 1999

April 1998

January 1998

December 2000

March 1998

November 2001

June 2002

May 1997

July 1998

April 2000

October 1998

December 2000

August 1998

December 1995

June 1999

April 2002

July 1995

January 1999

March 1998

January 1998

November 2002 
Banco John Deere

Banco Mercantil de Sao Paulo

Banco Real

Banco Santander

Banco Santander Brasil

Banco Santander Meridional

Banco Santander Noroeste

Banco Societe Generale Brasil

Banco UBS

Bank of America - Liberal

BCR Banco de Credito Real

Unicard Banco Multiplo
Domestic to Private

Domestic to Private

Domestic to Private

Domestic to Private

Domestic to Private

Domestic to Private

Domestic to Private

Domestic to Private

Domestic to Private

Domestic to Private

Domestic to Private

Domestic to Private
September 1999

March 2002

November 1999

May 2000

August 1997

May 2000

March 1998

October 1999

September 1998

October 2002

July 1998

January 2001

Banks that exited the sample

\begin{tabular}{|c|c|c|}
\hline Bank Name & Status & Exit Date \\
\hline Banco do Estado de Alagoas & Exit Liquidated State & July 1997 \\
\hline Banco do Estado de Mato Grosso & Exit Liquidated State & October 1998 \\
\hline Banco do Estado de Rondonia & Exit Liquidated State & August 1998 \\
\hline Banco do Estado de Roraima & Exit Liquidated State & December 1999 \\
\hline Banco do Estado do Acre & Exit Liquidated State & June 1999 \\
\hline Banco do Estado do Amapa & Exit Liquidated State & September 1997 \\
\hline Banco Aplicap & Exit Liquidated Private & January 1998 \\
\hline Banco Araucaria & Exit Liquidated Private & March 2001 \\
\hline Banco Bamerindus do Brasil & Exit Liquidated Private & April 1997 \\
\hline Banco BMD & Exit Liquidated Private & October 1998 \\
\hline Banco Brasileiro Comercial & Exit Liquidated Private & May 1998 \\
\hline Banco Brasileiro-Iraquiano & Exit Liquidated Private & May 1998 \\
\hline Banco Crefisul & Exit Liquidated Private & March 1999 \\
\hline Banco Empresarial & Exit Liquidated Private & May 1997 \\
\hline Banco Financial Portugues & Exit Liquidated Private & April 2002 \\
\hline Banco Hexabanco & Exit Liquidated Private & July 2000 \\
\hline Banco Interfinance & Exit Liquidated Private & August 1997 \\
\hline Banco Interior de Sao Paulo & Exit Liquidated Private & February 2001 \\
\hline Banco Interpart & Exit Liquidated Private & March 2001 \\
\hline Banco Lavra & Exit Liquidated Private & April 2000 \\
\hline Banco Martinelli & Exit Liquidated Private & October 1999 \\
\hline Banco Pontual & Exit Liquidated Private & October 1999 \\
\hline Banco Porto Seguro & Exit Liquidated Private & August 1997 \\
\hline Banco Santander Central Hispano & Exit Liquidated Private & May 2000 \\
\hline Banco Santander de Negocios & Exit Liquidated Private & August 2001 \\
\hline Banco Vega & Exit Liquidated Private & May 1997 \\
\hline Bancos Santos Neves & Exit Liquidated Private & August 2001 \\
\hline BANFORT - Banco Fortaleza & Exit Liquidated Private & May 1997 \\
\hline Milbanco & Exit Liquidated Private & November 1998 \\
\hline Banco Axial & Exit Changed & January 2001 \\
\hline Banco Bancred & Exit Changed & January 1998 \\
\hline Banco Boreal & Exit Changed & January 2002 \\
\hline Banco Cambial & Exit Changed & February 1998 \\
\hline
\end{tabular}




\begin{tabular}{|c|c|c|}
\hline Banco Chase Fleming & Exit Changed & December 2001 \\
\hline Banco Credito Metropolitano & Exit Changed & Januray 1998 \\
\hline Banco Criterium & Exit Changed & November 1997 \\
\hline Banco Destak & Exit Changed & June 1999 \\
\hline Banco Dimensao & Exit Changed & December 1997 \\
\hline Banco Equatorial & Exit Changed & June 2000 \\
\hline Banco Euroinvest - Eurobanco & Exit Changed & January 2002 \\
\hline Banco Exprinter Losan & Exit Changed & March 99 \\
\hline Banco Fenicia & Exit Changed & December 1999 \\
\hline Banco Ficrisa Axelrud & Exit Changed & November 2002 \\
\hline Banco Finansinos & Exit Changed & April 2002 \\
\hline Banco Fital & Exit Changed & October 1998 \\
\hline Banco Fonte Cindam & Exit Changed & December 2000 \\
\hline Banco Frances Internacional Brasil & Exit Changed & October 2001 \\
\hline Banco Gulfinvest & Exit Changed & December 1997 \\
\hline Banco HNF & Exit Changed & March 1999 \\
\hline Banco Icatu & Exit Changed & October 2001 \\
\hline Banco Induscred & Exit Changed & April 2002 \\
\hline Banco Investor & Exit Changed & September 1995 \\
\hline Banco lochpe & Exit Changed & February 1998 \\
\hline Banco Itamarati & Exit Changed & December 1997 \\
\hline Banco Marka & Exit Changed & January 2001 \\
\hline Banco Matrix & Exit Changed & December 2000 \\
\hline Banco Merrill Lynch & Exit Changed & December 2002 \\
\hline Banco Minas & Exit Changed & September 2000 \\
\hline Banco Misasi & Exit Changed & July 1996 \\
\hline Banco Multiplic & Exit Changed & August 1998 \\
\hline Banco Norchem & Exit Changed & July 1997 \\
\hline Banco OK & Exit Changed & July 1996 \\
\hline Banco Patente & Exit Changed & December 1999 \\
\hline Banco Performance & Exit Changed & November 1996 \\
\hline Banco Porto Real & Exit Changed & September 2001 \\
\hline Banco Prime & Exit Changed & December 1995 \\
\hline Banco Regional Malcon & Exit Changed & December 2001 \\
\hline Banco Royal & Exit Changed & December 1997 \\
\hline Banco Sistema & Exit Changed & September 2002 \\
\hline Banco Tecnicorp & Exit Changed & August 1999 \\
\hline Banco Tendencia & Exit Changed & December 2001 \\
\hline Banco Theca & Exit Changed & July 2001 \\
\hline Banco Wachovia & Exit Changed & April 2002 \\
\hline HSBC Investment Bank Brasil & Exit Changed & March 2002 \\
\hline HSBC Republic Bank Brasil & Exit Changed & December 2001 \\
\hline
\end{tabular}


Appendix 2: Descriptive statistics for the sample variables

TABLE 6 - Sample summary

\begin{tabular}{|c|c|c|c|c|c|}
\hline Variable & Mean & Median & $\begin{array}{l}\text { Standard } \\
\text { Deviation }\end{array}$ & Minimum & Maximum \\
\hline \multicolumn{6}{|l|}{ Production Function - 4444 obs. } \\
\hline Assets $^{*}$ & 5,001 & 557.5 & 18,511 & 0.680 & 206,047 \\
\hline Assets+Services* & 5,050 & 561.8 & 18,703 & 0.680 & 207,895 \\
\hline Employees & 3,261 & 129 & 12,381 & 2 & 136,587 \\
\hline Capital* & 123.9 & 7.268 & 648.2 & 0.00235 & 13,890 \\
\hline Other intermediate inputs* & 21.27 & 1.067 & 78.85 & 0.00240 & 972.3 \\
\hline Communications* & 6.712 & 0.464 & 25.34 & 0.000370 & 314.3 \\
\hline \multicolumn{6}{|c|}{ Determinants of Productivity - 4202 obs. } \\
\hline TFP1 & 7,123 & 2,291 & 18,316 & 88.11 & 441,776 \\
\hline TFP2 & 7,103 & 2,311 & 18,192 & 93.51 & 438,587 \\
\hline Market share & $0.59 \%$ & $0.073 \%$ & $2.25 \%$ & $0.00012 \%$ & $44.17 \%$ \\
\hline Number of branches & 94.77 & 3 & 347.3 & 0 & 3282 \\
\hline Return on net worth & 0.206 & 0.098 & 2.564 & -51.15 & 146.9 \\
\hline Dummy static state & 0.0283 & 0 & 0.1659 & 0 & 1 \\
\hline Dummy static foreign & 0.1735 & 0 & 0.3787 & 0 & 1 \\
\hline Dummy static domestic private & 0.2980 & 0 & 0.4574 & 0 & 1 \\
\hline Dummy exit liquidated state & 0.0181 & 0 & 0.1333 & 0 & 1 \\
\hline Dummy exit liquidated private & 0.0728 & 0 & 0.2599 & 0 & 1 \\
\hline Dummy exit liquidated change & 0.1416 & 0 & 0.3487 & 0 & 1 \\
\hline \multirow{2}{*}{$\begin{array}{l}\text { Dummy selection privatized } \\
\text { Dummy selection federalized } \\
\text { privatized }\end{array}$} & 0.0319 & 0 & 0.1757 & 0 & 1 \\
\hline & 0.0376 & 0 & 0.1903 & 0 & 1 \\
\hline Dummy selection restructured & 0.0288 & 0 & 0.1673 & 0 & 1 \\
\hline Dummy selection domestic & 0.1694 & 0 & 0.3752 & 0 & 1 \\
\hline \multirow{3}{*}{$\begin{array}{l}\text { Dummy dynamic privatized } \\
\text { Dummy dynamic federalized } \\
\text { privatized date federalization } \\
\text { Dummy dynamic federalized } \\
\text { privatized date privatization }\end{array}$} & 0.0093 & 0 & 0.0959 & 0 & 1 \\
\hline & 0.0105 & 0 & 0.1018 & 0 & 1 \\
\hline & 0.0019 & 0 & 0.0436 & 0 & 1 \\
\hline Dummy dynamic restructured & 0.0081 & 0 & 0.0896 & 0 & 1 \\
\hline Dummy dynamic domestic & 0.0462 & 0 & 0.2099 & 0 & 1 \\
\hline Time since privatized ${ }^{\star \star}$ & 0.0433 & 0 & 0.5241 & 0 & 11 \\
\hline \multirow{2}{*}{$\begin{array}{l}\text { Time federalized privatized since } \\
\text { date federalization } \star \star \\
\text { Time federalized privatized since } \\
\text { date privatization } \star \star\end{array}$} & 0.0412 & 0 & 0.4623 & 0 & 10 \\
\hline & 0.0050 & 0 & 0.1281 & 0 & 5 \\
\hline Time since restructured ${ }^{\star \star}$ & 0.0348 & 0 & 0.4426 & 0 & 9 \\
\hline Time since domestic change ${ }^{\star \star}$ & 0.2270 & 0 & 1.1387 & 0 & 11 \\
\hline
\end{tabular}

* in million of Reais (December 2002 values).

** in semesters. 


\section{REFERENCES}

ANDIMA-IBGE (1997). Sistema Financeiro: Uma Análise a Partir das Contas Nacionais 1990-1995. Rio de Janeiro, Andima \& IBGE.

Baer, W., and Nazmi, N. (2000). "Privatization and restructuring of banks in Brazil”, Quarterly Review of Economics and Finance, 40, 3-24.

Beck, T., Crivelli, J. M., and Summerhill, W. (2003). "State bank transformation in Brazil - choices and consequences”. Conference on Bank Privatization, World Bank.

Beck, T., Cull, R., and Jerome, A. (2003). "Bank privatization and performance: empirical evidence from Nigeria”. Conference on Bank Privatization, World Bank.

Berger, A., and Hannan, T. H. (1998). "The efficiency cost of market power in the banking industry: a test of the 'quiet life' and related hypotheses”, Review of Economics and Statistics, 80, 454-465.

Berger, A., and Humphrey, D. (1992). "Measurement and efficiency issues in commercial banking”, in Griliches, Z. (editor) Output Measurement in the Service Sectors. University of Chicago Press, NBER.

--------- (1997). "Efficiency of financial institutions: international survey and directions for future research”, European Journal of Operational Research, 98, 175-212.

Berger, A., Clarke, G. R. G., Cull, R., Klapper, L., and Udell, G.F. (2003). “Corporate governance and bank performance: a joint analysis of the static, selection, and dynamic effects of domestic, foreign, and state ownership, including domestic M\&As, foreign acquisitions, and privatization”. Conference on Bank Privatization, World Bank.

Bevilaqua, A. (2000). “State-government bailouts in Brazil”. Department of Economics, PUC, Rio de Janeiro, Discussion Paper no. 421.

Bevilaqua, A., and Loyo, E. (1998). “Openess and efficiency in Brazilian banking”. Department of Economics, PUC, Rio de Janeiro, Discussion Paper no. 390.

Boehmer, E., Nash, R. C., and Netter, J. M. (2003). "Bank privatization in developing and developed countries: cross-sectional evidence on the impact of economic and political factors”. Conference on Bank Privatization, World Bank. 
Bonaccorsi di Patti, E., and Hardy, D. C. (2003). “The effects of banking system reform in Pakistan”. Conference on Bank Privatization, World Bank.

Bonin, J. P., Hasan, I., and Wachtel, P. (2003). "Privatization matters: bank performance in transition countries”. Conference on Bank Privatization, World Bank.

Clarke, G. R. G., Cull, R., and Shirley, M. (2003). "Empirical studies on bank privatization: an overview”. Conference on Bank Privatization, World Bank.

Fixler, D. J., and Zieschang, K. D. (1992). "User costs, shadow prices, and the real output of banks”, in Griliches, Z. (editor) Output Measurement in the Service Sectors. University of Chicago Press, NBER.

Haber, S., and Kantor, S. (2003). "Getting privatization wrong: the Mexican banking system, 1991-2003”. Conference on Bank Privatization, World Bank.

Haynes, M., and Thompson, S. (1999). “The productivity effects of bank mergers: evidence from the UK building societies”, Journal of Banking and Finance, 23, 825-846.

Levine, R. (1997). "Financial development and economic growth: views and agenda”, Journal of Economic Literature, 35, 688-726.

Levinsohn, J., and Petrin, A. (1999). "When industries become more productive, do firms? Investigating productivity dynamics”, NBER Working Paper No. 6893.

---------- (2003). “Estimating production functions using inputs to control for unobservables”, Review of Economic Studies, 70, 317-342.

Megginson, W. (2003). “The economics of bank privatization”. Conference on Bank Privatization, World Bank.

Muendler, M.-A. (2002). "Trade, technology, and productivity: a study of Brazilian manufacturers, 1986-1998”. Mimeo, University of California, San Diego.

Nakane, M. I. (1999). “Productive efficiency in the Brazilian banking sector”. Mimeo, IPE-USP, Seminar 20/99.

Ness, Jr., W. L. (2000). "Reducing government bank presence in the Brazilian financial system. Why and how”, Quarterly Review of Economics and Finance, 40, 71-84.

Nguyen, N., and Williams, J. (2003). “Liberalisation, ownership and efficiency issues: a comparative study of South East Asian banking”. Conference on Bank Privatization, World Bank.

Olley, G., and Pakes, A. (1996). "The dynamics of productivity in the telecommunications equipment industry”, Econometrica, 64, 1263-1297. 
Omran, M. (2003). "Privatization, state ownership, and the performance of Egyptian banks”. Conference on Bank Privatization, World Bank.

Otchere, I. (2003). “Do privatized banks in middle- and low-income countries perform better than rival banks? An intra-industry analysis of bank privatization”. Conference on Bank Privatization, World Bank.

Schor, A. (2004). "Heterogeneous productivity response to tariff reduction: evidence from Brazilian manufacturing firms”. NBER Working Paper No. 10544.

Werlang, S. R. da C., and Fraga Neto, A. (1995). “Os bancos estaduais e o descontrole fiscal: alguns aspectos”, Revista Brasileira de Economia, 49, 265-275. 